\title{
Correction to: Dealing with loss of life across the spectrum of humankind
}

\section{David F. Albertini ${ }^{1}$}

Published online: 29 June 2020

(C) Springer Science+Business Media, LLC, part of Springer Nature 2020

\section{Correction to: Journal of Assisted Reproduction and Genetics (2020) 37:1265-1266} https://doi.org/10.1007/s10815-020-01858-8

The references of the original version of this article unfortunately were missing. The refences are shown below.

\section{References}

1. Wilcox AJ, Harmon Q, Doody K, Wolf DP, Adashi EY. Preimplantation loss of fertilized human ova: estimating the unobservable. Hum Reprod. 2020;35(4):743-50.

2. Hertig AT, Rock J. Searching for early fertilized human ova. Gynecol Investig. 1973;4(3):121-39.

3. Hertig AT, Rock J, Adams EC. A description of 34 human ova within the first 17 days of development. Am J Anat. 1956;98(3): 435-93.

4. Frazier T, Hogue CJR, Bonney EA, Yount KM, Pearce BD. Weathering the storm; a review of pre-pregnancy stress and risk of spontaneous abortion. Psychoneuroendocrinology. 2018;92:142-54.

Publisher's note Springer Nature remains neutral with regard to jurisdictional claims in published maps and institutional affiliations.

The online version of the original article can be found at https://doi.org/ $10.1007 / \mathrm{s} 10815-020-01858-8$

David F. Albertini

eicjarg@gmail.com

1 Bedford Research Foundation, Bedford, MA, USA 